\title{
form
}

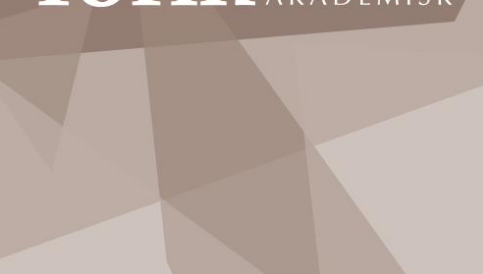

Vol I4, No 2 (202I)

\section{Artistic Expression and Material Limitations}

\section{An Iterative Process of Porcelain Making}

\begin{abstract}
This paper explores the iterative process of striving for artistic expressivity and developing crafting techniques in a porcelain-making project. The paper is about mitigating the tensions and flaws in porcelain bodies by trying out technical solutions while searching for genuine porcelaneous expressivity in artmaking. The paper presents examples of a working process of material-based art, from the first samples of material collapse to an exhibition of finished works in an art gallery, allowing the reader to see how faults and failures contribute to this development. The paper advocates that craft science and artistic research are closely integrated and intertwined.
\end{abstract}

Key words:

Artistic research, craft research, porcelain, material expressivity

\section{INTRODUCTION}

The title of this paper, Artistic Expression and Material Limitations, represents the objective and limitations of an ongoing three-year artistic research project, The Porcelaneous Project. The project resides in the field of material-based art, in Norwegian called kunsthåndverk. This is a movement from the 1970s, which at the time focused on utilitarian artefacts handmade by artisans in their own studios. The previous era of brukskunst (arts and crafts) had a different orientation, including industrial production. Over time, kunsthåndverk has progressed from the field of applied art to fine art, with the demand for good craftsmanship prevailing. The origin of the crafting expertise in specific materials is reflected in the still ongoing grouping of artefacts and their makers in the categories of metal, wood, ceramics and textiles. The current paper resides in the overlapping area of craft research and artistic research; these fields of study are related to the Nordic tradition of the making professions (DuninWoyseth \& Michl, 2001). 
The artworks of the project are black and white porcelain boards, partly hand-built, partly casted. Porcelain is a highly demanding material, causing a high rate of unsuccessful pieces. Material challenges need to be overcome in the process of making these boards. Two problems are crucial to address: material tensions, which can cause fracturing, and the sintering process, which can cause deformations during kiln firing. These two problems are intertwined.

The overarching objective of the Porcelaneous Project is to achieve artistic expressivity. The efforts to overcome technical problems are directed at this goal. Hence, the best solutions from a technical point of view may not be suitable if they do not support artistic expression. On the other hand, explorations of the potential of the material is the aim because the very objective of making porcelain boards is that they shall be porcelaneous, that is, the smooth and translucent material, the sheer white colour and the fragility and strength that allows porcelain objects to be very thin and light. Why bother with this problematic clay if painting on canvas would be just as good? Hence, the material character of porcelain, as well as its problematic tensions during construction and firing, is a core issue of the project. From this, the research question emerges: How can the material expressivity of porcelain be used in artworks, and how can the technical limitations of this material be challenged to enhance this expressivity?

\section{CRAFT SCIENCE AND ARTISTIC RESEARCH}

Bengt Molander describes craft science as an emerging field of research that combines science and craft. In this respect, he argues that the academic community must be open to expressions other than the traditional ones, which used to be lingual, and be open to practical knowledge traditions (Molander, 2017). He describes science as a collectively organised search for viable theories and knowledge, while still being open to criticism. Science is about qualified understanding and knowledge, problem understanding, communication and argumentation and the use of methods in a field of study. Sciences as a methodologically limited practice is an important inner delineation (Molander, 2017, p. 28). On artistic research, Henk Borgdorff argues the following:

(...) we can justifiably speak of artistic research (research in the arts) when that artistic practice is not only the result of the research, but also its methodological vehicle, when the research unfolds in and through the acts of creating and performing. (2011, p. 46)

Craft science and artistic research are both emerging fields of research. They are affiliated fields of study and, as I see it, are closely intertwined. One can hardly speak of artistic research in the visual and material arts without bringing in a craft component. However, craft science does not necessarily deal with the making of art. At the same time, they are both within fields of research where gaining knowledge through and by practice is the pivotal feature. Indeed, the Nordic tradition of the making disciplines includes both.

As an artistic research enterprise, the Porcelaneous Project is a contribution -though minorto the knowledge base of the making disciplines. In Dunin-Woyseth's words, the knowledge base should be 'the intellectual identity of a field of study' (Dunin-Woyseth, 2005, p. 161). As the intellectual identity of a discipline, the knowledge base needs to be developed from inside the discipline for the members of the discipline to take control of it. On the other hand, contributions from other disciplines are needed, for example, techniques and materials, sustainability, art and design history and more (Solberg, 2017). Regarding the knowledge base as a matter of academic identity, I regard what Dunin-Woyseth describes as the making knowledge to include the particular creative practice component of the making disciplines. However, Molander discusses the emerging craft science from the perspective of theory, regarding theory as a vehicle for structuring a reality that should go beneath the surface of empirical observations and experiences to expose the fundamental constituents of reality (Molander, 2017, p. 17). In the debate of research in art and in craft, there is a frequent proposition that the knowledge of the making disciplines is something different. In the 1980s, Donald Schön argued that universities tended to reject knowledge that included practical competence and professional artistic performance. 
At the same time, he also observed that the professionals in these fields failed to concretise the character of their knowledge (Schön, 1983, pp. vii-viii). In the present discussion, making knowledge tends to relate to the concepts of tacit knowledge (Polanyi, 2009) and embodied, situated and enacted forms of cognition (Borgdorff, 2013b, p. 116).

\section{METHODS}

The project being followed in the current paper is conducted with an experimental approach, that is, not with the notion of experimental art as an epoch of art history, but as experiments in a series of systematic conducted efforts of materials and techniques to gain knowledge on the subject in question. Most of these experiments have a problem-solving orientation. However, at the same time, there is also an explorative approach to artistic expression. In Dyrssen's words, explorative experiments should shake up ingrained patterns of thought, discover hidden possibilities and get the creative process moving forward (Dyrssen, 2011, p. 229). I have emphasised an open character of experiments, allowing unforeseen results to occur, affect the project and even change the direction of the project or split into a bifurcation of experimental lines, as in Rheinberger's model of experimental systems and epistemic things (Rheinberger, 1997; Solberg, 2020.)

The insider perspective is characteristic of research where knowledge is gained through practice. In Hannula's words, research is done inside-in, while reaching out and getting out of one's comfort zone to return to it again is not superimposed from the outside, but developed and taken care of from within. The process is a collection of acts that is not called progress but instead a never-ending, self-reflective and critical creative process (Hannula et al., 2014, p. 14). As I see it, even if problematic, the insider's advantage is the knowledge of the making process and considerations of the artist, which no one else can achieve. Thus, the artist-researcher can lead his or her audience backstage to see what is usually hidden from the public to gain a deeper understanding.

In the Porcelaneous Project, I have the insider's perspective of a practising researcher while also aiming to see the process from an outsider's perspective by means of documentation and reflection. The series of experiments are documented in a written logbook and in a photographic logbook on the working process and artworks. Some flaws and failures are kept as empirical material, and some are rejected and thrown out after documentation. The photographs in the present article are examples from the photographic logbook. The movements of kneading and twisting the plastic clay are documented by photographs only. In retrospect, I realise that video documentation would have been a better alternative because movement is an essential component, both in the working process and in the final results.

In the current paper, the examples are chosen to illustrate the technical and material problems and the interaction between working on solving the problems and gaining artistic expressions in the final results. The examples are presented chronologically to expose the development of craft techniques and artistic expressions.

\section{THE PORCELAIN BOARDS}

The examples are provided from an ongoing craft project of making porcelain boards; they are glimpses of progress from the first efforts of making porcelain boards via numerous misfortunes of cracking and collapse, eventually leading to an exhibition at my university campus in Notodden, Norway. Technically, the project deals with a major problem of porcelain making: inherent tensions in the boards during making and tensions and deformations caused by the high temperature during kiln firing. These are two sides of the same coin, both causing fractures and warping.

The very first finding regarding material tensions occurred when sizing up the artworks from $30 \times 0 \mathrm{~cm}$ tiles to boards of $40 \times 40 \mathrm{~cm}$. There was almost no technical problems with the $30 \times 30 \mathrm{~cm}$ tiles. On the larger boards, however, the technical problems proved to be numerous. This transition immediately showed that size is a crucial criterion. In the following, all efforts concern $40 * 40 \mathrm{~cm}$ boards. This is also the first example of artistic expression overruling technical solutions. The whole project would have been so much easier keeping the $30 \times 30 \mathrm{~cm}$ size. However, this size looked too much like 
bathroom tiles, far from the artistic expressions that I was trying to create. The very resemblance of tiles on the bathroom wall excluded further progress on the $30 \times 30 \mathrm{~cm}$ tiles.

\section{TENSIONS, FRACTURES AND PROBLEM SOLVING}

The first boards were made using an old Japanese crafting technique: Nerikomi. This is a highly developed crafting technique with characteristic visual results. It is well-known from porcelain bowls and dishes. Using this technique for flat boards, however, proved to cause some technical challenges, fracturing in particular, from minor cracks to full material collapse.

\section{Full Material Collapse}
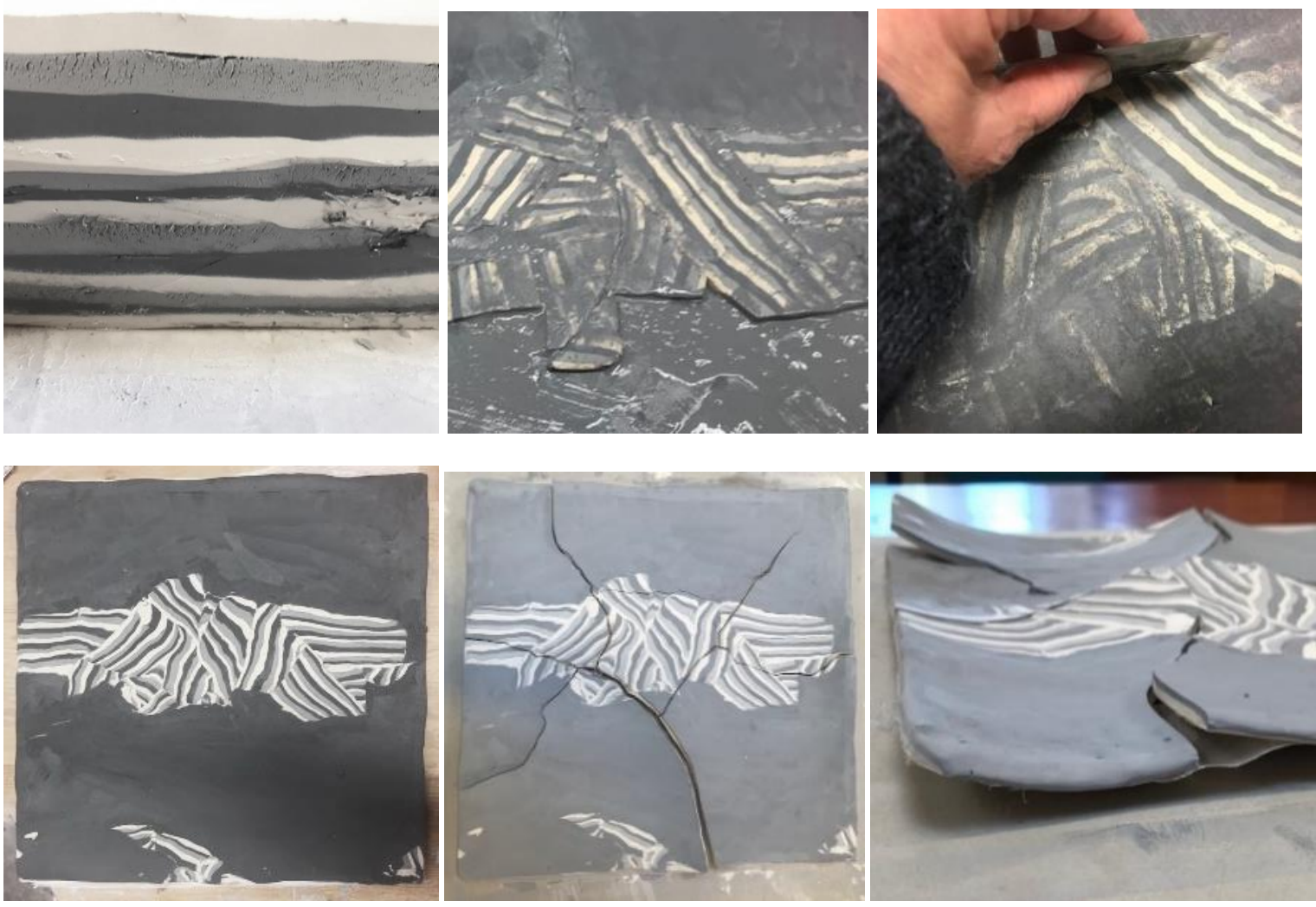

Figure 1. Material collapse of the first Nerikomi board. Unfired. December 2019.

The problems with the Nericomi board (Figure 1) emerged during the drying process. Small fractures at the edges propagated across the entire board, which in turn dissolved into warped pieces that did not fit well with each other. Even before firing, there was a total material collapse of this board. The reason was obvious: as seen in the right image, there are two layers of porcelain, one white and one black. The bottom layer, the white clay, was cast in a plaster mould. This is a swift and safe method for making boards with no fracturing. The second layer, the black clay, was a plastic clay that I also use for handbuilding, which was added on top of the white one. What caused the fracturing was that the casting clay and plastic clay have different material characteristics. In the drying process, the two layers of clay were shrinking differently, causing the total cracking and warping of the board.

In the following, I used one kind of clay only-one black and one white-both plastic clays made for handwork and made by the same clay producer to match one another. 


\section{Propagating Fractures}

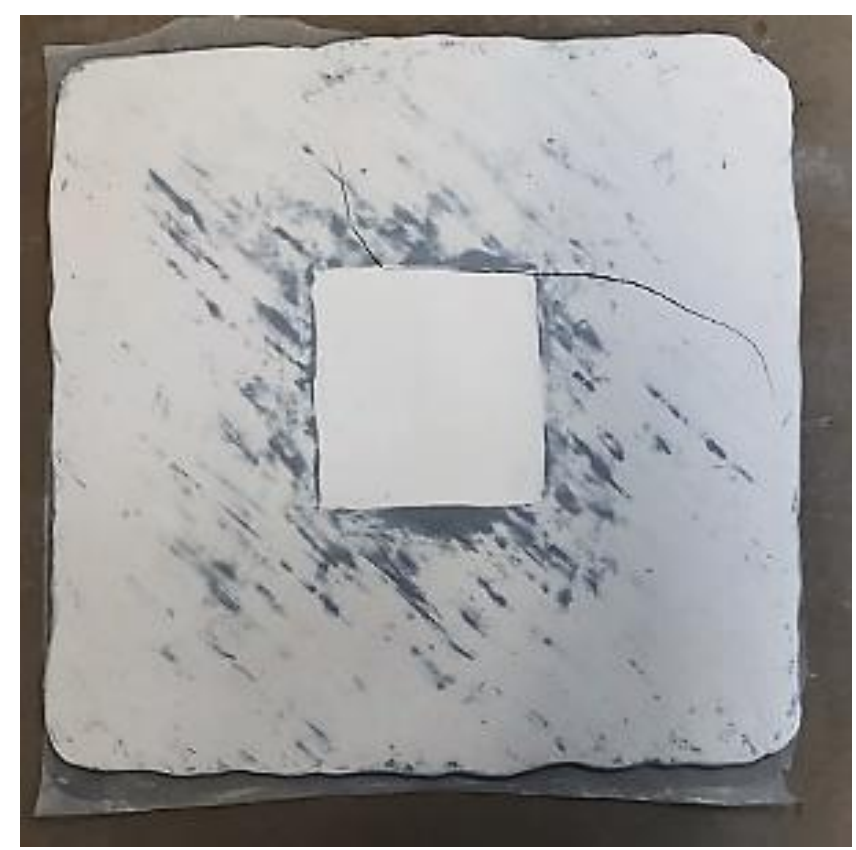

FIGURE 2. An initial fracture at the border between the white and black clays propagated further in two directions. March 2019

One of the first series was a number of black, hand-built porcelain boards with a white square in the middle; in addition, there were variations of translucent white clay painted on it like layers of fog (Figure 2). From a systematic experiment perspective, the black and white squares were constant, and the translucent areas were variables. In some boards, fractures occurred the line of assembly between the white and black clay. A number of measures needed to be tried out to mitigate this problem. What proved to be the most robust technique was to attach the white square on the board with an amount of slip, pressing it a bit with a rolling tool, then turning the board upside down so that the inserted clay was pressed into the board. Then, the clay on the back was removed so that the entire board had the same thickness. The board was then turned again, and the white, translucent layer was painted with a white slip.

My initial idea was to impose a white square throughout the black sheet of clay so that the board would be identical on both sides. This proved to be too vulnerable, at least with this particular clay. Hence, material limitations made this idea for the artwork impossible.
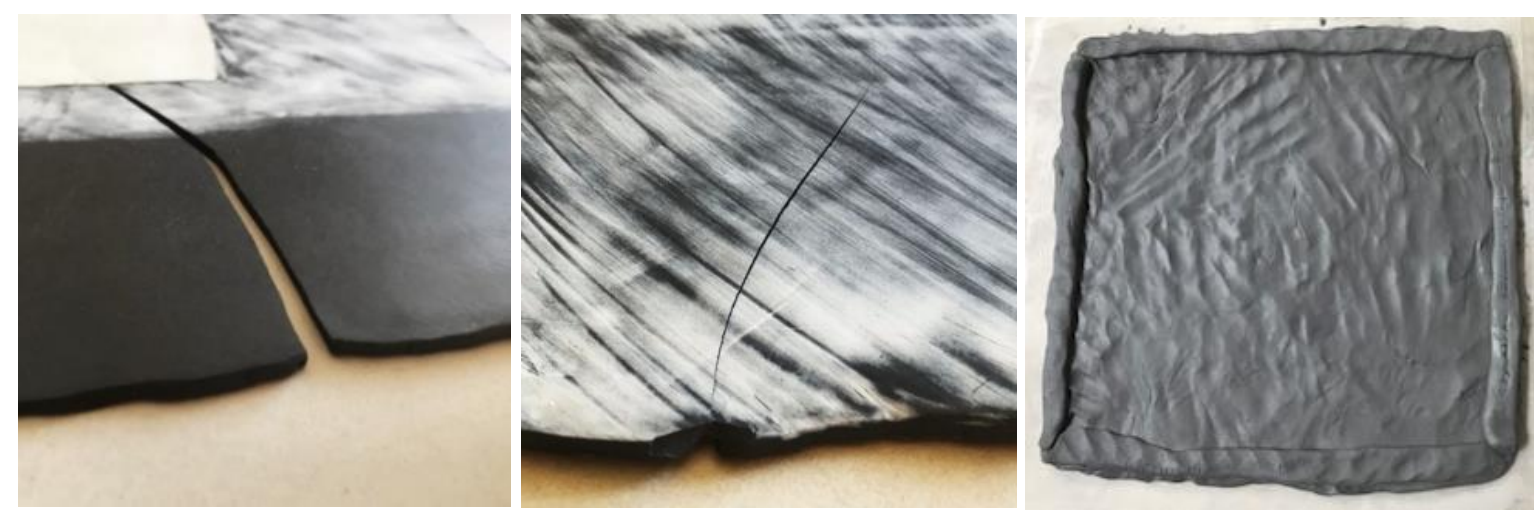

FIGURE 3. Fracture from the edges and an attempt to mitigate this problem by strengthening the edges of the board in the handbuilding process. April 2019. 
Occasionally, cracks on the edges occurred during the last phase of drying. These propagated during firing, sometimes across the entire board. I used several remedies to address this problem. First, I slowed down the drying process and then covered the edges with plastic sheets because the edges dry faster than the middle of the board. I also followed advice from a ceramic handbook that suggested adding a rim of clay to the edges during making and beating it into the clay body to strengthen the edges from the outside (ECWC, 2005). A small crack caused by an impurity on a shelf in the kiln propagated across the board. The impurity consisted of just a very small drop of glaze and grog. To remedy this, I ensured that kiln shelves were clean and reserved for this project only.

I had to ditch my idea of exposing the character of handmaking and the traces of handwork by leaving the edges uneven and rough. On the contrary, I had to smooth them as much as possible to avoid making trigger points for propagating fractures.

\section{Searching for Explanations}

In sum, the efforts of making porcelain boards exposed that tensions can cause fractures both from the edges and from the centre of the boards. For the most part, cracking occurred during drying, particularly in the last phase. Initially, small cracks propagated during drying, handling and firing. In this respect, the size of the boards was crucial. There was no fracturing in small tiles.

A ceramic handbook (ECWC, 2005) referring to research on the ceramic process states that there is an increased risk of cracking in the leather-hard and brittle phases, the latter in particular. The explanation is that in wet clay, the particles of the material have a continuous film of water around them, and the pores are filled with water. This makes the clay flexible. In the leather-hard/brittle stages, flexibility decreases rapidly. This makes it harder for water to reach the surface of the body. As a result, the surface dries faster and shrinks more than the inner part of the material. This causes a build-up of inner tension. The handbook provides several suggestions for how to secure drying as evenly as possible. The overall key is to slow down the drying process (ECWC, 2005, pp. 136-138).

A textbook in materials science and engineering (Callister \& Rethwisch, 2015) describes the quantification of relationships between material properties, stress level, the presence of crackproducing flaws and crack propagation mechanisms. For most materials, the measured fracture strength tends to be much lower than that suggested by theoretical calculations based on atomic bonding energies. This is because of microscopic flaws that always exist under normal conditions or macroscopic internal discontinuities, such as sharp corners, scratches and notches. When tensile stress reaches a critical level, cracking occurs, followed by propagation. From an engineering perspective, a critical level of tension can be calculated (Callister \& Rethwisch, 2015, pp. 291-294). Ceramic fracturing is a major problem for industries manufacturing electrical devices, space installations and dental works. For this reason, there has been a series of annual international symposia on ceramic fracturing with a number of conference proceedings, for example, the 1996 proceedings on R-curve behaviour, toughness determination, and thermal shock (Bradt et al., 1996). Hence, in searching for ways to deal with fracturing, the ceramic artist is not alone. In the following is a series of images from the engineering book and the examples from my porcelain project, showing that the fractures of my boards act precisely as described in engineering theory (Figures 4 and 5). 

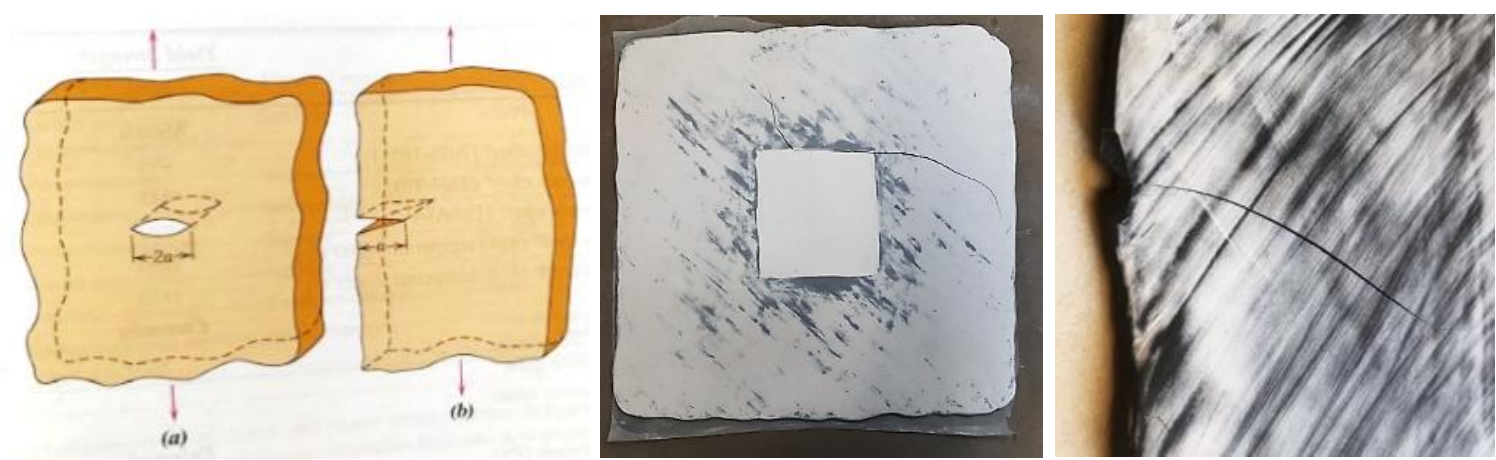

FIGURE 4. Schematic representations of interior and edge cracks in boards of infinite width (Callister \& Rethwisch, 2015, p. 295). Examples in porcelain boards.

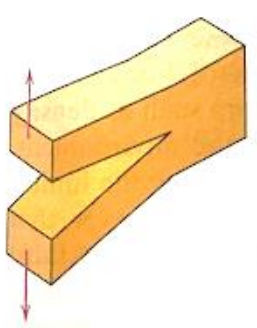

(a)

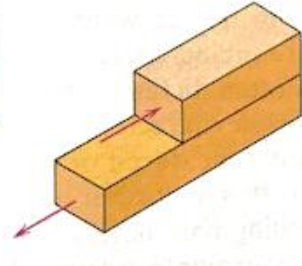

(b)

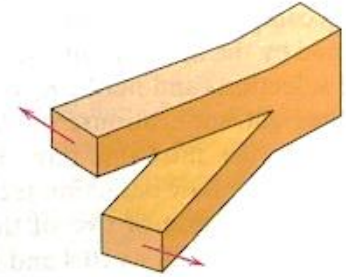

(c)

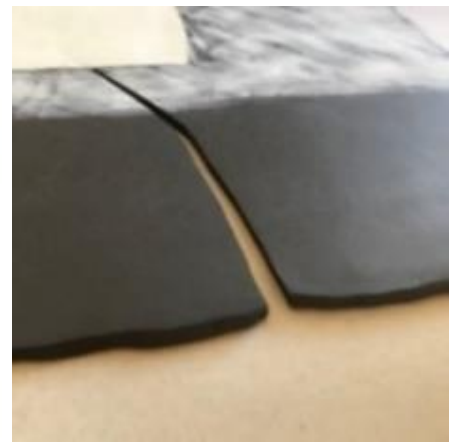

FIGURE 5. The three modes of crack surface displacement: (a) opening or tensile mode, (b) sliding mode and (c) tearing mode (Callister \& Rethwisch, 2015, p. 295). The porcelain board has an opening or tensile mode fracture (as in image a).

Stress tensions are embedded in the material because of the geometric structures of the clay. Tensions also build up during the making process. In terms of the shrinkage process, one might think that the size of boards is of little importance because the pro ratio shrinkage is the same throughout. However, this is not the case. From an engineering perspective, the total amount of shrinkage is crucial. Hence, engineering knowledge is helpful for understanding and mitigating the causes and propagation of fractures.

\section{Plasticity and Movements}

My search for the porcelaneous includes an exploration of the particular character of porcelain clay: plastic and workable when wet, hard and stable when fired. Figures 6 and 7 show examples of how this plasticity can be used for artistic expression.

The figurative images on the clay boards were not planned at the beginning of the project; they are examples of the unforeseen, creating a new line of experiments, thus causing a bifurcation of the project into two different lines (Solberg, 2020). By allowing open-ended experiments, an initially technical experiment of handling clay allowed the emergence of a new artistic concept to be the starting point of a new artistic exploration.

The cracking all across this board exposed the fragility of this type of construction. Meticulous considerations were needed to obtain successful results. Most of the fractures occurred along the construction assembly lines, from the edges of the boards in particular. I realised that the edges of the board should be as coherent as possible and that by any insertion of different clays, a rim of solid clay should be left around the edges. This is a substantial limitation of the artistic expression I had planned. Hence, I had to change the concept of triptychs, as in the example below (Figure 8). 

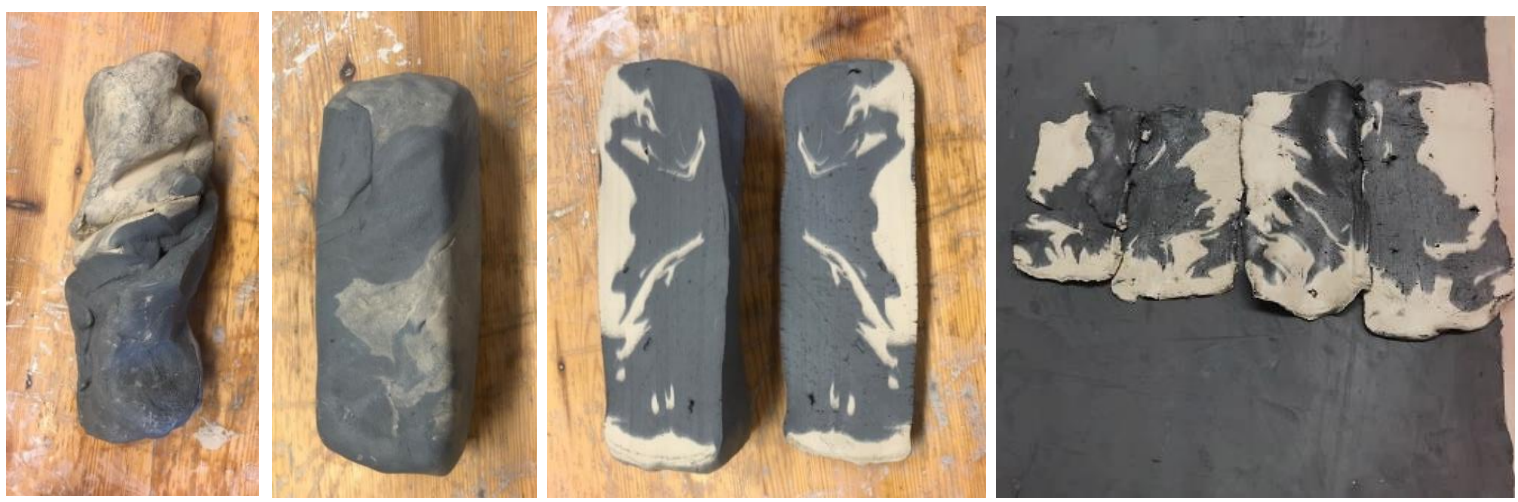

Figure 6. Movements created by handling plastic clay. From the left: Kneading and twisting equal parts of black and white clay. Cutting slices, assembling them on the black clay board. April 2020
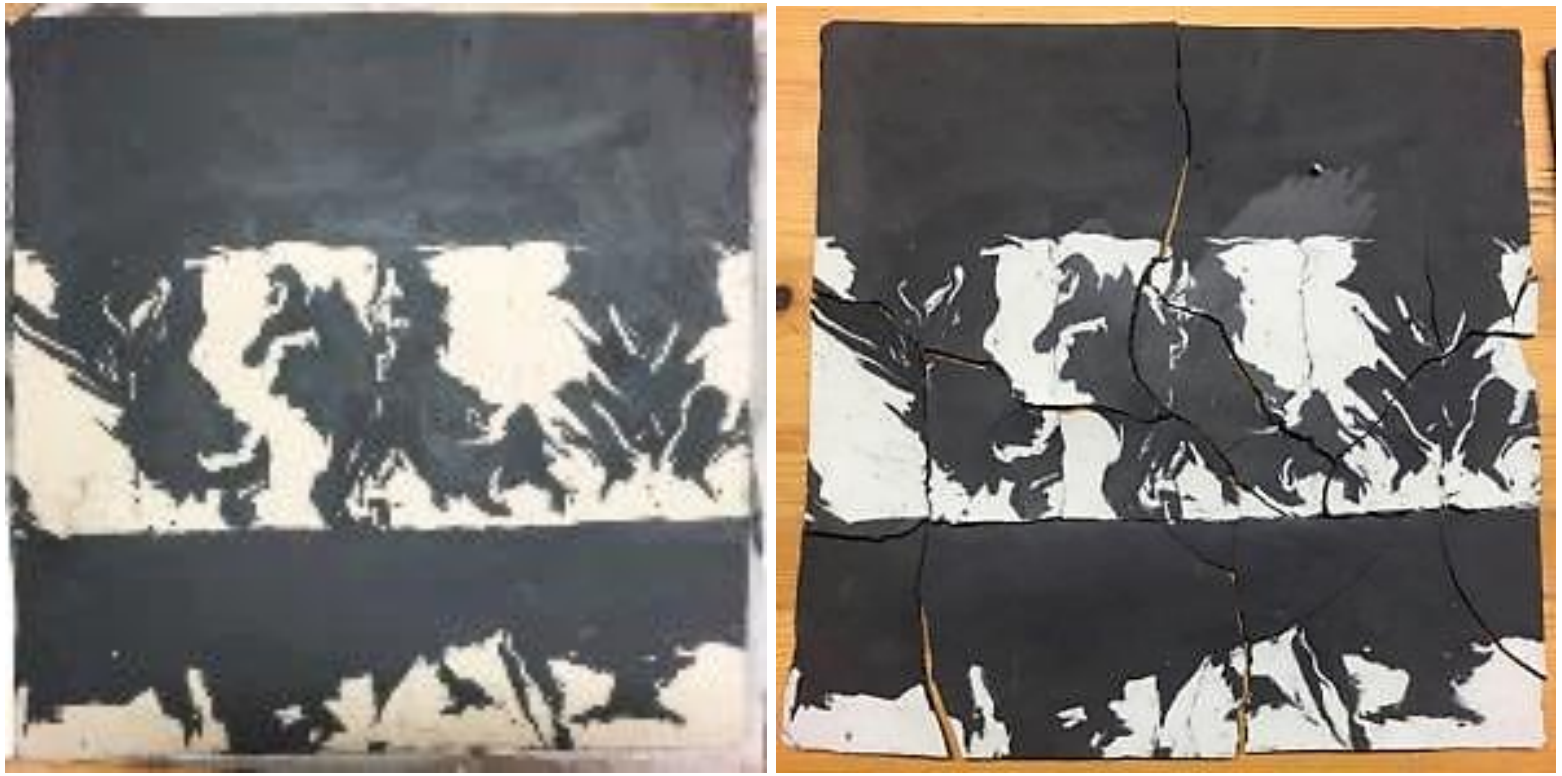

Figure 7. Material collapse of the intarsia board of Figure 6. Fractures from the centre, partly following the lines of the inserted white clay. Left: Finished board, unfired. Right: The fired board. A multitude of cracks occurred during drying, propagating during firing. April 2020.

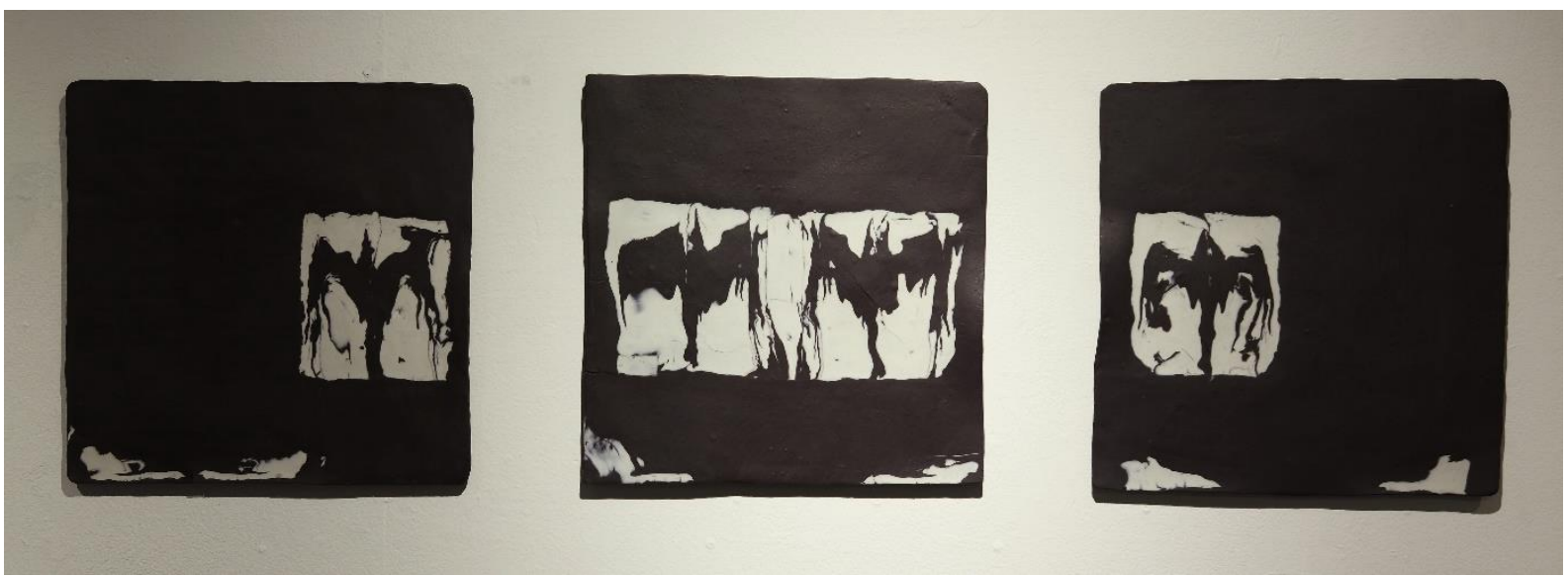

Figure 8. The Animal Strikes Back. The Viral Bat. April 2020. Photo from an exhibition at the Foaje Gallery at the University of South-Eastern Norway, October 2020. Photo: Marek Podowski 
This triptych (Figure 8) had to deviate from the original plan, which was a continuous white shape crossing the three boards. Instead, I had to leave a black frame around each board, making quite a different expression.

The images of what I see as a bat occurred in an associative process of assembling slices of black and white clay on the boards to make some kind of pattern. Images sometimes became so strong that my original position in the material-based art tradition would fade. In these cases, the project was an artistic research enterprise rather than one of craft science, though both were still present and intertwined.
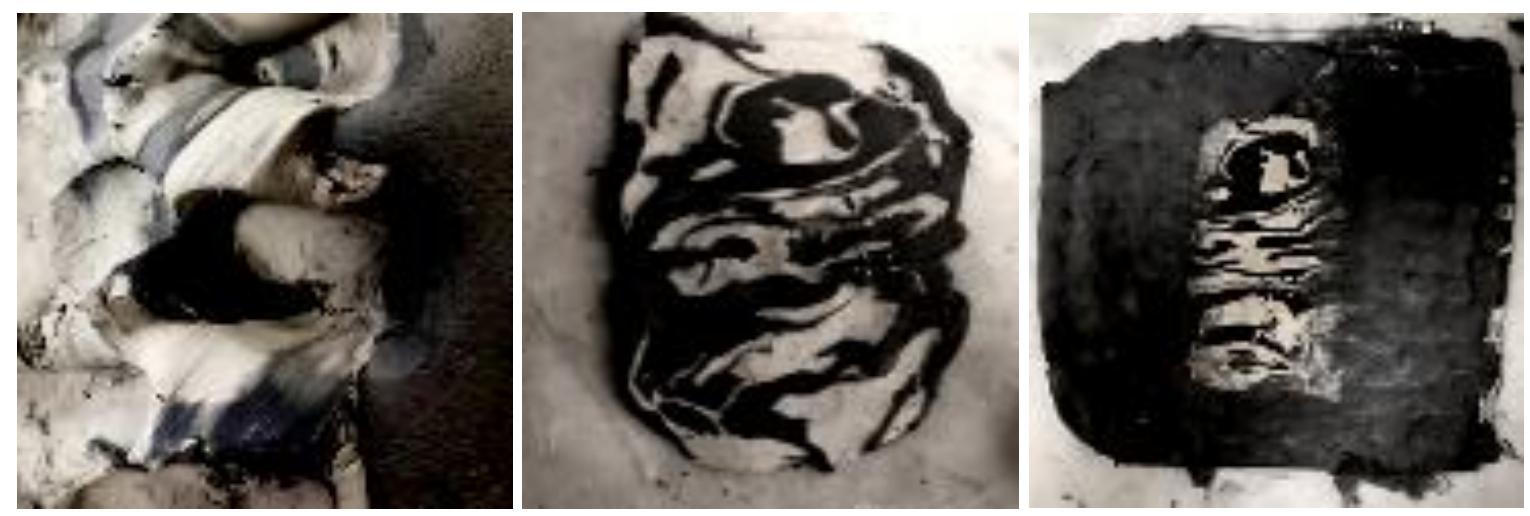

Figure 9. Plasticity and traces of the movement of hands. May 2020.

The plasticity of clay allows fluid and continuous movements by hands when kneading and twisting the clay. A lump of kneaded clay (Figure 9) exposes marbling structures similar to that of nature's marble stone, which develops by pressure and tensions over millions of years. Clay and rocks are made of the same minerals, and their plasticity can be traced as soft patterns in the stone's hard material. The characteristic marbling patterns are made of fluid lines similar to those that can be seen in fluid liquids.

Five steel cases (Figure 10) were constructed for the exhibition in the Foaje Gallery for the exhibition in October 2020. The steel frame was produced in $20 \mathrm{~mm}$ steel profiles. The porcelain boards were held up by four $0.3 \mathrm{~mm}$ steel wires, with steel bolts keeping them in place on the wires. This makes the boards hang freely and vertical.

When cropping the marbled slice of clay to the form of a rectangle and inserting it into a square board, there is an absolute contrast between the fluid lines and the geometric shapes. Being mounted in a strictly constructed steel display case underscores the contrast between the fluid lines of the soft clay and the geometrical environment. 


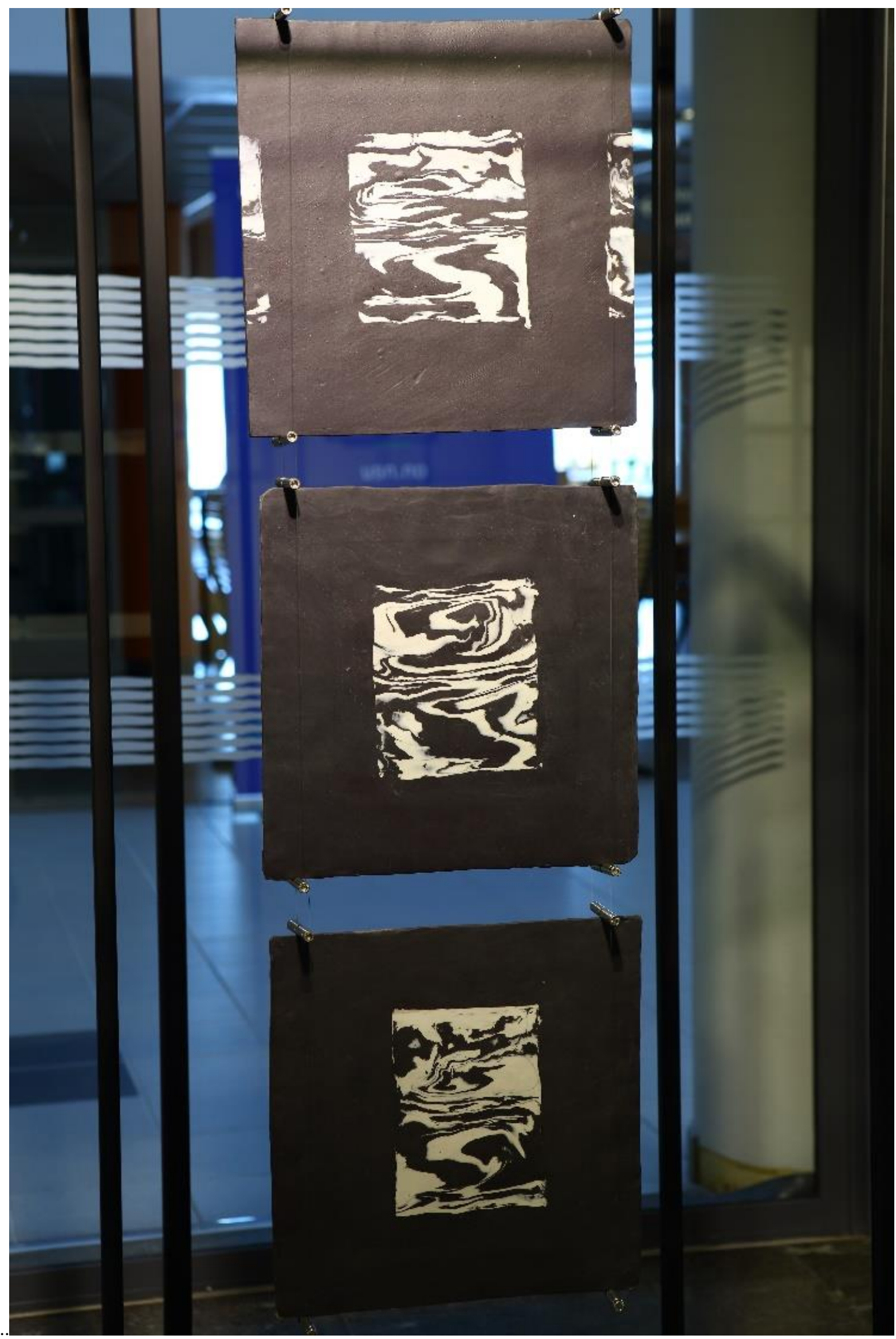

Figure 10. Porcelain boards in a steel display case in the Foaje Gallery exhibition at USN, Notodden, October 2020. Design and construction: Jon and Øystein Grøstad. Production: Telemark Technologies. Photo: Marek Podowski. 


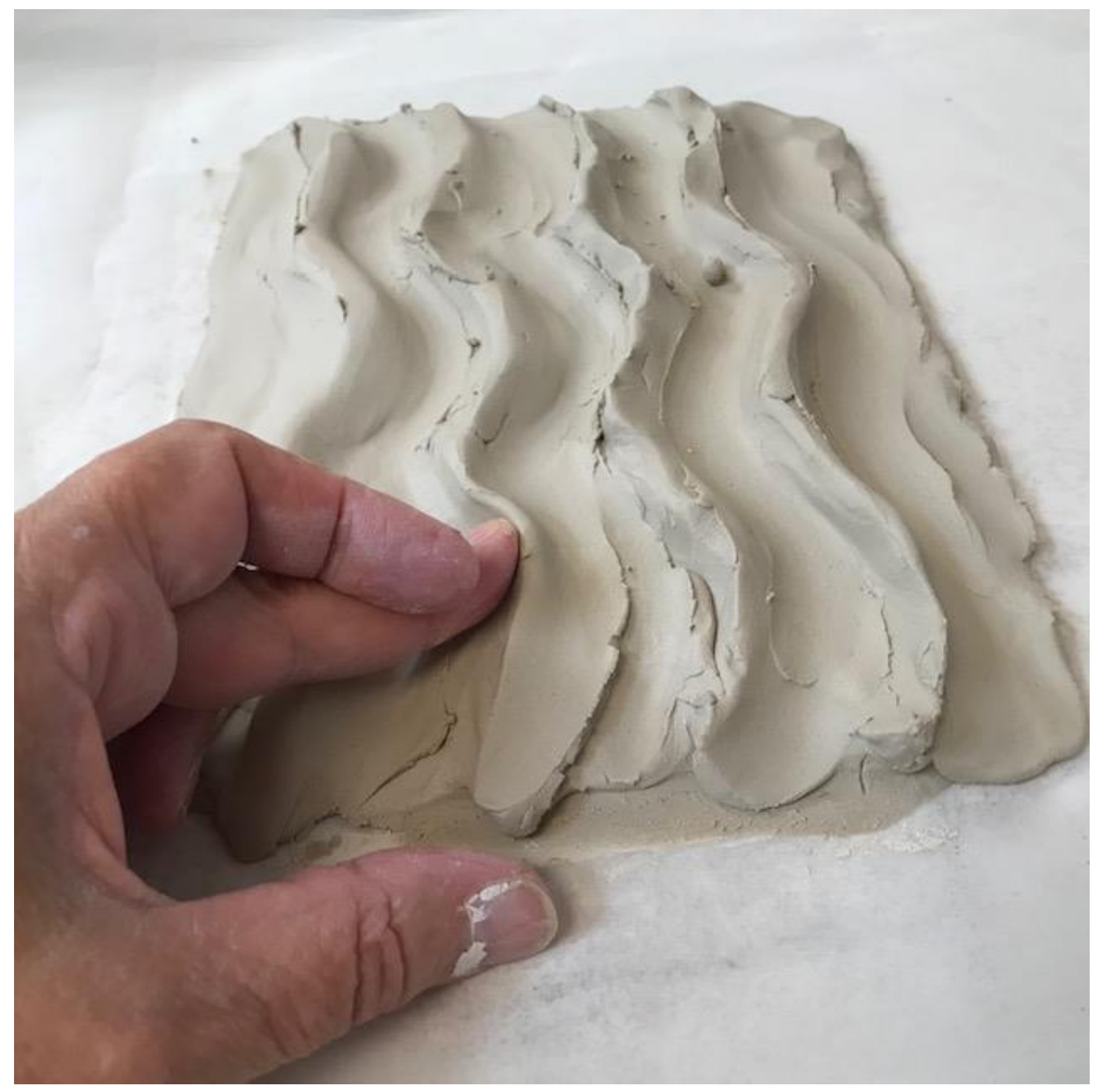

Figure 11. Making a mould for a three-dimensional structure on porcelain boards. September 2020.

In a further search for 'the porcelaneous', the plasticity of clay can be used for three-dimensional structures in porcelain boards. I tried to model clay forms in a sturdy stoneware clay (Figure 11), using them as moulds for imposing structures into casted sheets of porcelain clay. Because of the shrinking of the porcelain body during drying, the stoneware forms had to be removed as soon as the porcelain was leather-hard. I kneaded $10 \%$ molochite, a white grog, into the clay as a strengthening addition. Still, particular care was needed for the structured boards to withstand the top temperature in the kiln without collapsing. This creates substantial limitations for three-dimensional structures on a porcelain board. However, similar to the black boards with the intarsia (Figure 10), the fired results of the white $3 \mathrm{D}$ boards reflected the soft flexibility of the clay (Figure 11).

When making porcelain artworks, self-supportive constructions need to be in the crafter's mind. Over time, I achieved a bodily feeling of how far the structures can evolve before collapsing. I had to accept that this limit is embedded in the porcelain material. To succeed, the crafter needs to accept this character of the material and work with it instead of against it. Achieving an embodied knowledge of the material's limits and obtaining an artistic expression of quality are developed in a meticulous, iterative process. 


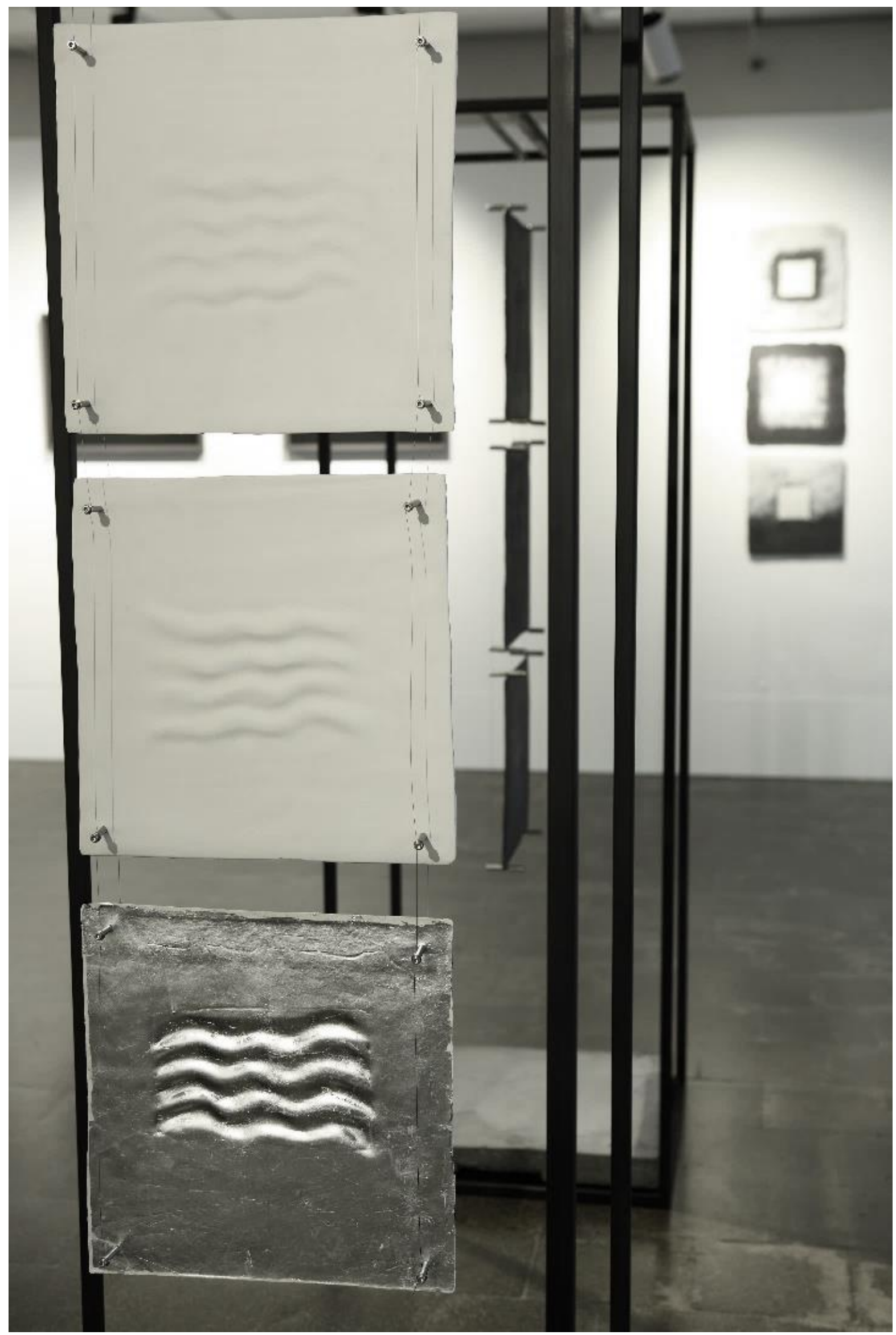

Figure 12. Porcelain boards in a steel display case in the Foaje Gallery at USN, Notodden, October 2020. Design and construction of the case: Jon and $\varnothing$ ystein Grøstad. Production: Telemark Technologies. Photo: Marek Podowski 
The white structured boards were mounted in a steel display case (Figure 12) like the one used for the black intarsia boards (Figure 10). The three-dimensional structure makes a negative form on the back side of the boards; that is, these boards are two-sided. There are holes in the corners of the boards, with steel bolts inserted through them. This integrates the boards into a larger construction, underscoring that they are not images like the ones in glass and frame but rather are things, solid hardware. The soft plasticity of the clay is transformed into hard, square shapes in a steel construction, even emphasised by the alumina-plated surface of the bottom board.

\section{Concluding Comment}

Because kunsthåndverk crossed the border of fine art, leaving the identity of making things for everyday use, their new category can be questioned. The term 'material-based art' reflects this transition. As I see it, even if the artworks have crossed the border into fine art, they are still things, even if they are no longer utensils, neither do they match the category of paintings and prints in glass and frames. Materialbased art is something in-between. The boards of the Porcelaneous Project are partly placed on the gallery walls and partly in steel cases, where they are fastened with steel bolts. The latter categorises them as things.

As a crafter of material-based art, I concentrate on the artistic expressivity of materials that I have learned to handle as a crafter. My artworks are not within the field of concept art or site-specific art, nor are they representations or figurative narratives. What I look for is the genuine character of the material, the material's expressivity, which in this project is the porcelaneous. Hence, as I see it, materialbased art resides in a combined field of study of craft science and artistic research.

The craft perspective of this project has been all about mitigating flaws and fractures. However, one question should be asked: Why not regard the fractures as a characteristic of this material and use this as an expression? This is another way to cross the border for material-based art: leaving the ideal of technical perfectionism. Below highlights the unfortunate item with its cracks, which is then changed with a coat of silver (Figure 13).
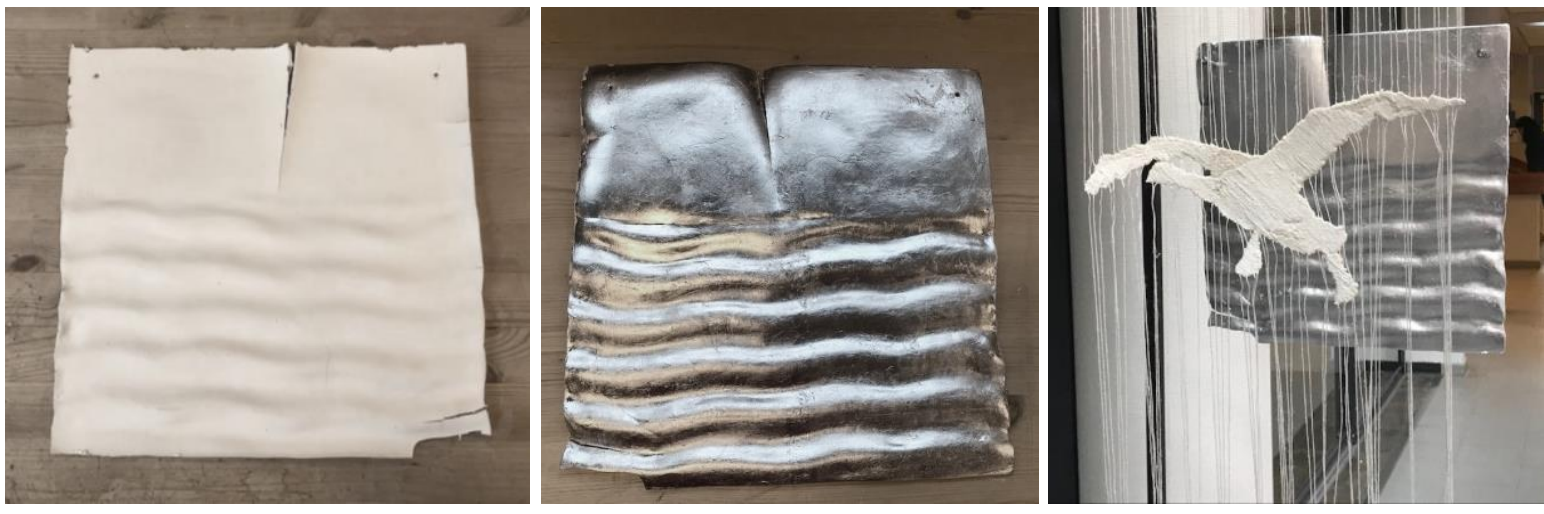

Figure 13. The honour of the Unfortunate. Left: Cracks that occurred in the firing. Middle: Added metal sheet to the surface. Right: As a background for the duck 'Vassplask' by Ellen Baskår, silk thread sewed with a digital sewing machine. Exhibition at USN, campus Notodden, October 2020. 


\section{REFERENCES}

Borgdorff, H. (2011). The production of knowledge in artistic research. In M. Biggs \& H. Karlsson (Eds.), The Routledge companion to research in the arts (pp. 44-63). Routledge.

Borgdorff, H. (2013). Artistic practices and epistemic things. In M. Schwab (Ed.), Experimental systems future knowledge in artistic research. Leuven University Press.

Bradt, R. C. E., Hasselman, D. P. H., Munz, D., Sakai, M., \& Shevchenko, V. Y. (1996). Fracture mechanics of ceramics 11 (Vol. 11). Springer Science and Business Media. https://doi.org/10.1007/978-1-4615-58538

Callister, W. D., \& Rethwisch, D. G. (2015). Materials science and engineering (9th ed., SI version ed.). Wiley.

Dunin-Woyseth, H. (2005). The 'thinkable' and 'unthinkable' doctorates. Three perspectives on doctoral scholarship in architecture. In J. Michl \& L. M. Nielsen (Eds.), Building a doctoral programme in architecture and design: Appreciations from colleagues and friends of Halina Dunin-Woyseth's contributions on the occasion of her 60th birthday (pp. 149-176). AHO, Oslo School of Architecture and Design.

Dunin-Woyseth, H., \& Michl, J. (2001). Towards a disciplinary identity of the making professions research magazine (Vol. Research Magazine no 4). http://janmichl.com/eng.millreader.pdf

Dyrssen, C. (2011) Navigating in Heterogeneity. In M. Biggs \& H. Karlsson. The Routledge Companion of Research in the Arts. Routledge. Dyrssen, C. (2011) Navigating in Heterogeneity. In M. Biggs \& H. Karlsson. The Routledge Companion of Research in the Arts (pp. 223-239). Routledge. http://clab.iat.sfu.ca/804/uploads/Main/RoutledgeCompanion.pdf

ECWC. (2005). European Ceramic Work Centre. The ceramic process. A manual and source of inspiration for ceramic art and design. University of Pennsylvania Press.

Hannula, M., Souranta, J., \& Vadén, T. (2014). Artistic research methodology. Narrative, power and the public. Peter Lang Publishing. https://doi.org/10.3726/978-1-4539-1308-6

Molander, B. (2017). Om tankens frihet och längtan efter verklighet. Om 'teori' som begrepp och retorik. In G. Almervik (Ed.), Hantverksvetenskap (pp. 15-38). Göteborgs Universitet. http://hdl.handle.net/2077/52386

Polanyi, M. (2009). The tacit dimension. University of Chicago Press.

Rheinberger, H.-J. (1997). Toward a history of epistemic things: Synthesizing proteins in the test tube. Stanford University Press.

Schön, D. A. (1983). The reflective practitioner: How professionals think in action. Basic Books.

Solberg, A. (2017). Developing Doctorateness in Art, Design and Architecture. [PhD thesis, University of SouthEastern Norway] https://brage.bibsys.no/xmlui/bitstream/handle/11250/2442970/Thesis.pdf?sequence=4

Solberg, A. (2020). Enigmatic epistemic things. The epistemic role of artworks in artistic research doctorates. FormAkademisk 2020, 13(3). https://doi.org/10.7577/formakademisk.3543 